Review

\title{
Is mTOR Inhibitor Good Enough for Treatment All Tumors in TSC Patients?
}

\author{
Samy L Habib1,4凶${ }^{\bowtie}$, Noor Y Al-Obaidi' ${ }^{4}$, Maciej Nowacki², Katarzyna Pietkun², Barbara Zegarska², Tomasz \\ Kloskowski², Wojciech Zegarski², Tomasz Drewa², Edward A. Medina ${ }^{3}$, Zhenze Zhao ${ }^{4}$ and Sitai Liang ${ }^{4}$ \\ ${ }^{1}$ Geriatric Research Education and Clinical Center, South Texas, Veterans Healthcare System; ${ }^{2}$ Collegium Medicum, Bydgoszcz and Nicolaus Copernicus \\ University, Torun, Poland; ${ }^{3}$ Department of Pathology and ${ }^{4}$ Department of Cellular and Structural Biology, University of Texas Health Science Center, San \\ Antonio, Texas 78229, USA \\ $\triangle$ Corresponding author: Dr. Samy L Habib, The University of Texas Health Science Center, 7703 Floyd Curl Dr., San Antonio, TX 78229. Tel: 210-567-3816; Fax: \\ 210-567-3802; Email: habib@uthscsa.edu
}

(C) Ivyspring International Publisher. Reproduction is permitted for personal, noncommercial use, provided that the article is in whole, unmodified, and properly cited. See http:/ /ivyspring.com/terms for terms and conditions.

Received: 2015.12.18; Accepted: 2016.03.15; Published: 2016.07.21

\begin{abstract}
Tuberous sclerosis complex (TSC) is an autosomal dominant and multi-system genetic disorder in humans. TSC affects around 25,000 to 40,000 individuals in the United States and about 1 to 2 million individuals worldwide, with an estimated prevalence of one in 6,000 newborns. TSC occurs in all races and ethnic groups, and in both genders. TSC is caused by defects or mutations in two genes, TSC1 and TSC2. Loss of TSC1/TSC2 leads to dysregulation of mTOR, resulting in aberrant cell differentiation and development, and abnormal enlargement of cells. TSC is characterized by the development of benign and/or malignant tumors in several organs including renal/liver angiomyolipomas, facial angiofibroma, lymphangiomyomatosis, cardiac rhabdomyomas, retinal astrocytic, renal cell carcinoma, and brain subependymal giant cell astrocytomas (SEGA). In addition, TSC disease causes disabling neurologic disorders, including epilepsy, mental retardation and autism. Particularly problematic are the development of renal angiomyolipomas, which tend to be larger, bilateral, multifocal and present at a younger age compared with sporadic forms. In addition, SEGA block the flow of fluid within the brain, causing a buildup of fluid and pressure that leads to blurred vision and seizures. In the current review, we describe the pathology of TSC disease in key organs and summarize the use of mTOR inhibitors to treat tumors in TSC patients.
\end{abstract}

Key words: TSC, mTOR inhibitors, LAM, AML, SEGA.

\section{TSC as a multiorgan genetic disease}

TSC is a genetic disease that can appear in individuals who inherit the disorder from a parent with TSC; however, most cases occur sporadically due to spontaneous mutations in TSC1 or TSC2. TSC disease is associated with the frequent occurrence of benign tumors and a variety of symptoms that include seizures, cognitive impairment, behavior problems, and skin abnormalities. Tumors can develop in many organs, but most commonly occur in the brain, kidneys, heart, lungs, and skin. Malignant tumors are rare and occur primarily in the kidney. Several pathological aspects of the manifestation of TSC disease in key organs and current treatments that target mTOR in TSC patients will be described herein.

\section{A. Brain tumor}

Subependymal giant cell astrocytoma (SEGA) is a brain tumor associated with tuberous sclerosis complex (TSC). It usually develops in the second decade of life, but can occur during the first months of life. Congenital SEGA develops in $2.2 \%$ of TSC patients. Patients with TSC2 mutations, especially TSC2/PKD1 mutations, are more prone to develop SEGA earlier in childhood thereby necessitating screening for SEGA from birth onwards. In young infants with SEGA, both surgery and mTOR inhibitor 
therapy should be considered. Although the mTOR inhibitor Everolimus has been approved for SEGA associated with TSC by the FDA and EMA, the data on its safety and efficacy in newborns and infants with SEGA is very limited (1).

Grossly, these tumors are well circumscribed, exophytic lesions that have a uniformly gray white or mottled pink cut surface. Subependymal giant cell astrocytoma is histologically identical to subependymal nodules, or so-called candle drippings, which found intraventricularly and constitute one of the diagnostic criteria of tuberous sclerosis (2). Indeed, subependymal giant cell astrocytoma is distinguishable from subependymal nodules only by its propensity to expand/grow; the biologic events mediating this propensity for growth are unclear, although some tumors show loss of heterozygosity for either the TSC1 or TSC2 gene (3).

Both subependymal giant cell astrocytomas and subependymal nodules may be composed of large ganglioid or balloon cells with prominent nucleoli that range in size from gemistocytes to balloon-shaped ganglion cells. Spindle-shaped cells can predominate in some tumors (4). Rates of regrowth after resection of SEGA are low, making surgical resection a potentially curative therapeutic strategy. Additional benefits of mTOR inhibition in patients with TSC may include shrinkage of angiofibromas and angiomyolipomas as well as a decrease in seizure burden. While recent reports of successful nonsurgical treatment of SEGAs are promising, further specifics on dosing, duration, and long-term outcome are needed to enable patients and their physicians to make better-informed therapeutic choices (5).

\section{B. Treatment of brain tumor}

Pharmacological treatment of SEGA aims to achieve shrinkage and/or stabilization of the tumor. Rapamycin and Everolimus are mTOR inhibitors that have been shown to be highly efficacious against SEGA. Unfortunately, in most cases, tumors regrew with cessation of therapy. However, the US Food and Drug Administration (FDA) approved Everolimus for treatment of SEGA. Everolimus is very similar to Rapamycin with respect to chemical composition: a 2-hydroxyethyl group has been introduced in position 40 of Rapamycin. This change results in a slight increase in bioavailability and a shorter half-life. The adverse-effect profiles of the two drugs appear very similar (5). Patients treated with mTOR inhibitors had a mild improvement in seizure burden, although it is unclear whether this effect was due to decreased intracranial pressure or a direct effect of these agents on the seizure focus. Longer follow-up of patients undergoing mTOR inhibition therapy may shed light on the duration of treatment needed to prevent regrowth of SEGAs in TSC patients. Fortunately, a number of clinical trials are evaluating the efficacy of Sirolimus or Everolimus against SEGA.

\section{Sirolimus}

A multi-center study recently demonstrated that Sirolimus was effective therapy against multiple tumors in various organs (6). A total of 36 patients were involved in the study wherein Sirolimus was administered at $6 \mathrm{mg} /$ day one and then $2 \mathrm{mg} /$ day for a median period of 24 months. The most noticeable adverse effects were stomatitis, hypertriglycemia, hypercholesterolemia and bone marrow suppression.

More recently in 2015, Sirolimus was administrated to five of six patients with the $6^{\text {th }}$ patient receiving Everolimus. An initial dose of 4 $\mathrm{mg} / \mathrm{m} 2 /$ day for both drugs was effective for tumor shrinkage, but a subsequent dose of less than 2.5 $\mathrm{mg} / \mathrm{m} 2$ was not effective in maintaining the response and tumor re-growth was noted; re-incrimination of the dose was needed to again achieve tumor shrinkage. The ideal effective dosage of Sirolimus and Everolimus was $4-5 \mathrm{mg} / \mathrm{m} 2 /$ day in order to achieve treatment efficacy (tumor shrinkage more than 50\%). The main concern regarding Sirolimus, which was not observed with Everolimus, was its negative effect on the growth of pertinent. Adverse effects seen with both drugs included loss of appetite and menstrual irregularity in female patients (7).

\section{Everolimus}

A number of studies have evaluated Everolimus for the management of SEGA. The most recent clinical trials, categorized according to the type of the study. Prospective open label of 1-2 phase trial: in a trial involving 28 patients that started in 2010, rapid reduction in tumor size was noticed in the first few months of therapy. Drug dosage was initially 3 $\mathrm{mg} / \mathrm{m} 2$ and then $5.5 \mathrm{mg} / \mathrm{m} 2$ with the study continuing for a median length of time of 34.2 months (8). A long period of follow up was needed to evaluate safety and efficacy of the treatment. Notably, a decrease in seizure frequency was noted beside the benefit of tumor reduction. The main adverse effects were, stomatitis, respiratory infections, sinusitis, and otitis media. This study demonstrated that Everolimus treatment rapidly reduced SEGA volume (8), which was sustained over time (9). The study further demonstrated that Everolimus could be used for long term therapy (8), making it a good alternative to surgery in patients unsuitable for surgical resection. Limitations of this study included its open-label, single-arm design, and the small number 
of patients that underwent treatment. The extension phase of this study is ongoing, and efficacy and safety data continue to be monitored.

Single-centered open label study of 15 patients underwent therapy with $2.5-7.5 \mathrm{mg}$ of Everolimus for 13 months. A remarkable reduction in SEGA size was observed especially during the first 3 months of treatment (10). The main adverse effects included stomatitis, hypertension, respiratory infection and secondary amenorrhea The occurrence of amenorrhea supports the central role mTOR signaling has in pubertal onset, and highlights the need for further investigation of the mTOR inhibitor's effects on growth and child development. Multi-centered double blind, placebo controlled phase 3 trials: total of 117 patients were enrolled with 39 of them on placebo and the remainder administered $4.5 \mathrm{mg} / \mathrm{m} 2$ Everolimus initially and was continued for a median 29.3 months. Importantly, this study demonstrated that long-term use of Everolimus maintains its efficacy with acceptable tolerability in patients with TSC-associated SEGA. The main adverse effects were stomatitis and convulsions $(11,12)$.

Another single center open label series clinical study involved 6 patients. Using $3 \mathrm{mg}$ Sirolimus and/or $5 \mathrm{mg}$ Everolimus with median treatment duration of 13 months, this study demonstrated that the use of both drugs (13) induced a significant decrease in tumor size for all 6 patients. This small study supports other clinical trials that suggest that mTOR inhibitor therapy is an effective therapy may be effective and a good alternative for those patients unable to undergo surgical resection. The main side effects were dyslipidemia, gingivitis, and anorexia. A limitation of this study was the small number of patients. Notably, one of the patients suffered from recurrence of the tumor after Sirolimus therapy was stopped.

Because regrowth after surgical resection of SEGA is low, it is therapeutically efficacious and possibly curative. Gamma Knife ${ }^{\mathrm{TM}}$ therapy shows promise; however, evaluation of short- and long-term outcomes is needed to assess its efficacy and safety before it becomes standard of care (5). Medical versus surgical management of SEGAs is a subject of controversy. mTOR inhibitor therapy for SEGAs appears efficacious. Unfortunately it appears that regrowth can occur if treatment is stopped, raising the possibility that long-term medication may be required to prevent tumor growth and hydrocephalus. Moreover, adverse effects of mTOR inhibitors include immunosuppression (infections, mouth sores, etc.), hypercholesterolemia, and the need for chronic drug monitoring. However, surgery also has its risks including acute morbidity and the permanent need for ventriculoperitoneal shunting. Again, evaluation of the short- and long-term outcomes of Gamma $\mathrm{Knife}^{\mathrm{TM}}$ therapy, and specifics on dosing, duration, and long-term outcome of mTOR inhibitor therapy may better enable patients and their physicians to better evaluate among the therapeutic options for SEGA.

\section{A. Benign kidney tumor}

Renal Angiomyolipoma (AML) is benign kidney tumor occurs in approximately $80 \%$ of patients with TSC (14). AML is diagnosed using non-invasive methods, renal ultrasonography, computed tomography imaging (CT scanning) and magnetic resonance imaging (MRI), which yields the most detailed imaging of the kidney (14). AML is a non-malignant mesynchymal tumor composed of abnormal blood vessels, immature smooth muscle cells and fat cells. Angiomyolipomas can grow to where they develop aneurysms that can burst and bleed; this is life threatening approximately $20 \%$ of the time (14). The proportion of each component varies from one lesion to another, even when occurring in the same kidney. There is a direct relationship between angiomyolipoma size, aneurysm formation and spontaneous rupture. Ruptured angiomyolipomas usually have a tumor size of $4 \mathrm{~cm}$ or more and an aneurysm size of $5 \mathrm{~mm}$ or more (15). Herein, we highlight the most recent clinical trials that used mTOR inhibitors (both Sirolimus and Everolimus) to treat renal AML.

\section{B. Treatment of benign kidney tumor}

Clinical trials have been conducted to treat patients with Sirolimus can be classified into 3 main categories according to the type of the clinical trial:

\section{Sirolimus}

Non randomized open label trial: 25 patients were administered $0.25 \mathrm{mg} / \mathrm{m} 2$ for a median drug treatment period of 12 months with a 24 month follow up. In this clinical trial, all patients experienced a decrease in renal AML size as well as an improvement in pulmonary function. The study continued successfully for one year. All adverse effects, such as diarrhea, pyelonephritis, stomatitis and lung Infection, were manageable. Limitations of the study were the small number of patients, the lack of a control group, and limited data collected after therapy cessation (16).

Multicenter non-randomized open label trial: A total of 16 patients were treated with Sirolimus with an initial dosage of $0.5 \mathrm{mg} / \mathrm{m} 2$ with a median drug treatment period of 24 months. A decrease in tumor size was noticed during therapy. Unfortunately AML 
volume increased for several patients after therapy cessation. Some improvement in pulmonary function was achieved which tended to persist after therapy cessation. The main adverse effects were manageable and included mouth ulceration, respiratory infection and proteinuria. This study is considered the first example of therapeutic targeting of a tumor, arising as either a Mendelian or sporadic disorder, by inhibiting a key shared signaling pathway. Limitations of this study were the small number of patients, the lack of a control group and limited data regarding outcome after therapy cessation. (17)

Multicenter Phase 2 trial: 36 patients were treated with an initial dosage of $6 \mathrm{mg}$ (day one) and then $2 \mathrm{mg}$ daily with a median drug treatment period of 24 months. A decrease in tumor size was observed for lesions occurring in multiple organs (renal AML, SEGA, and liver AML). This is considered the first study that identified a potential useful biomarker (VEGF-D) for renal AML. The main adverse effects were stomatitis, hypertriglyceridemia, hypercholesterolemia, and bone marrow suppression. Limitations of this study were the small number of patients and the absence of pediatrics patients (6).

\section{Everolimus}

Two trials, both multicenter double blind controlled phase 3 trials, evaluated therapy with Everolimus. Trial 1 involved 44 patients with 30 receiving Everolimus and 14 patients receiving placebo. $4.5 \mathrm{mg} / \mathrm{m} 2$ Everolimus was administered for a median treatment period of 9.5 months (18). Trial 2: involved 118 patients with 39 patients receiving placebo and the remainder administered $10 \mathrm{mg}$ daily Evirolimus for a median drug treatment period of 9.5 months (19). Some manageable adverse effects were reported. Limitations for both trials were the small number of patients involved and lack of informative follow up.

A study conducted in 2014 evaluated the effect of Everolimus on AML volume in patients that were being treated for SEGA associated with TSC. Patients received $4.5 \mathrm{mg} / \mathrm{m} 2 /$ day for a targeted blood trough between $5-15 \mathrm{ng} / \mathrm{ml}$; the minimum plasma concentration was $3.6 \mathrm{ng} / \mathrm{ml}$ at week 2 then $2.9 \mathrm{ng} / \mathrm{ml}$ at week 4 then maintained at a relatively constant level between $4.5-7.7 \mathrm{ng} / \mathrm{ml}$ (from week 4 to week 48 ). This study revealed that Everolimus reduced AML volume; $35 \%$ of patients had a volume reduction of $50 \%$ or more (15).

Recent Study in 2015 showed that treatment with mTOR inhibitors (using Sirolimus for 12 months followed by 6 months fellow up) which is used originally for treatment of LAM has been more effective in the treatment of extrapulmonary manifestations and lead to a significant reduction in renal angiomyolipoma volume. However, certain aspects like optimal dose, duration of treatment and long term side effects have yet to be fully clarified (20). Beside the pharmaceutical therapy, AMLs can be treated by interventional embolization especially to patients who have spontaneous rupture of aneurysm or hemodynamically unstable (21).

\section{A. Malignant kidney tumor}

Malignant tumorigenesis in patients with TSC is rare. Malignancies have appeared in the kidney as renal cell carcinoma (RCC). RCC occurs in approximately $3 \%$ of TSC patients, developing typically $<50$ years of age (22). Development of RCC in TSC patients was described a few decades ago (23). However, it is possible that some RCCs were diagnosed as epithelioid angiomyolipomas, which may have contributed to uncertainty with respect to the frequency of RCCs in TSC. RCCs arise from the various specialized cells that comprise the nephron, which gives rise to the different histological cell types of RCC such as clear cell, papillary, chromophobe oncocytoma, and collecting duct RCC. Immunohistochemical methods, combined with morphology, enable classification of multiple types of RCC. The most common type of RCC that occurs in TSC patients (52\% of tumors) has a unique morphology that is distinct from the conventional forms of RCC. Features of this type of TSC-associated RCC include prominent papillary architecture and a uniform lack of immunostaining for succinate dehydrogenase (SDH) subunit $\mathrm{B}$, in contrast to most RCCs. This has prompted the term 'TSC-associated papillary $\mathrm{RCC}^{\prime}$. The second most common group of TSC-associated RCC (33\%) was morphologically similar to a hybrid oncocytic/chromophobe tumor. The third group of TSC renal epithelial neoplasms (15\%) had features distinct from the first two groups as well as classic types of RCC, and could not be classified further (22).

\section{B. Treatment of malignant kidney tumor}

Tumor resection (partial or total nephrectomy) is the only known effective treatment for localized RCC or for palliation in metastatic disease. However, mTOR inhibitors such as Everolimus and Sirolimus are considered standard agents for the management of advanced stages of RCC or as post-operative adjunctive therapy.

A small cohort study of outlier cases with exceptional response to mTOR inhibitors presented the first data linking genomic tumor analysis with long-term response to mTOR inhibitor therapy in advanced RCC (24). A total of 5 patients, were 
successfully treated with Temsirolimus or Everolimus for a median 28 months. Studies exploring clonal heterogeneity in the nephrectomy specimens or metastatic tissues from the 5 patients' revealed genomic alterations (TSC1 and MTOR) were having an activating effect on mTOR signaling in 11 of 14 total specimens. Loss of function in the TSC1 gene, a negative regulator of mTOR, was found in three of the five patients. Thus, oncogenomic events activating the mTOR pathway sensitized the patients' tumors to mTOR inhibitors and explain the exceptional treatment response that was observed. The findings from this study produced several candidate genes for future biomarker development for this class of agents. Two limitations of this study were the small number of patients participating in the study, and the lack of metastatic tissue specimens for some of the patients. (24).

In pediatric patients, the association between RCC and TSC is very rare; two cases were reported in 2011 (25). In both cases, renal RCC developed in infants and TSC developed later in childhood. Both cases had a mutation in the TSC2 gene; one of the infants developed papillary RCC (substitution of cytosine with thymine on exon 28) and the other developed clear cell RCC (deletion of guanine on exon 19), the most common type of RCC associated with TSC. Both infants underwent nephrectomy due to the large tumor size (25), even though avoiding nephrectomy in pediatric cases is preferred because of the tendency to develop angiomyolipoma in the future on the contralateral kidney. mTOR inhibitor therapy might be useful in such instances. Indeed, recent clinical trials have demonstrated RCC regression in response to Rapamycin in patients with TSC. In addition, tumor excision followed by Sirolimus therapy resulted a good response overall with minimal side effects (26).

\section{A. Liver tumor}

Liver angiomyolipoma is a very rare hepatic tumor that is well circumscribed, and comprised of fat, epithelioid, and smooth muscle cells with thick-walled blood vessels present. An association with tuberous sclerosis and renal angiomyolipoma was found in $10 \%$ of cases; there was a female preponderance (27). Complications of this rare tumor include compressive effects due to its large growth potential, and malignant transformation, although this occurs more rarely than in the kidney.

\section{B. Treatment of liver tumor}

Clinical trials that have evaluated the response of liver tumors to mTOR inhibitors have been discussed above in the context of their effects on tumors in other organs. For example, one study (6) using Sirolimus 6 $\mathrm{mg}$ on day one and then subsequently $2 \mathrm{mg}$ daily showed significant decreases in liver AML size, renal AML size and SEGA. The adverse effects and limitations of this trial were listed in the section summarizing the treatment of kidney tumors. A study evaluating mTOR inhibitors for the treatment of TSC-related diseases (28) revealed that Rapamycin and analogs reduced the size of SEGA and kidney angiomyolipoma but not liver angiomyolipomas.

Hepatic AML does not appear to transform to hepatocellular carcinoma (HCC). However, a single case report indicated the occurrence of a hepatic AML and HCC at the same location, indicating possible transformation, although the authors did suggest that might have occurred by coincidence. HCC is the most common malignant tumor of the liver and the $3^{\text {rd }}$ most common cause of cancer related mortality worldwide. The patient in this case was successfully treated with surgical resection of the tumor followed by one-month trans arterial chemoembolization (TACE) treatment; indeed, HCC needs to be removed surgically (29).

\section{A. Skin tumor}

Facial angiofibroma (AF) is a benign fibrous neoplasm comprised of a proliferation of stellate and spindled cells, thin-walled blood vessels with dilated lumina in the dermis; coarse concentric collagen bundles are present. Sporadic AFs or facial papules are indistinguishable from TSC-associated facial AFs (30). Facial AFs are considered one of the most obvious cutaneous manifestations of TSC, which start appearing at 3 to 4 years of age. The number and size of facial AFs varies markedly between patients, but they have the potential to become extremely unsightly. Typically, facial AFs do not improve spontaneously and are frequently treated because of disfigurement (31). Facial AFs develop first as small bumps that are usually scattered on the central face, especially on the nose and cheeks, and sometimes on the forehead, eyelids, and chin; they are often clustered in the grooves at the side of the nose (32).

AFs are typically smaller than a peppercorn, but can grow larger. They may be skin-colored, pink, or red. In darkly pigmented individuals they may be reddish brown or dark brown. People with TSC usually have multiple facial $\mathrm{AFs}$; some have hundreds. Individuals with three or more facial AFs meet one of the major diagnostic criteria for TSC. Facial AFs can begin in early childhood as flat red "spots", or as a diffuse redness of the cheeks, which is due to the proliferation of blood vessels. They later become elevated due to increased amounts of dense fibrous tissue, similar to what is found in a scar. Facial 
AFs are essentially overgrowths of normal skin components (hamartomas) that do not become malignant. However, a recent study revealed that sun exposure can cause additional ultraviolet 'signature' (second hit) mutations in facial AFs that are never seen as a TSC germline mutation, which suggests that sun protection may reduce the number and severity of angiofibromas (33).

\section{B. Treatment of skin tumor}

mTOR is aberrantly activated in the proliferating fibroblast like cells within the facial AFs. These cells produce an epidermal growth factor, epiregulin, which stimulates epidermal cell proliferation such that they are produced at a faster rate than the dead cells are sloughed from the skin surface. AFs of TSC have a prominent vascular proliferation owing to increased expression of angiogenic factors such as vascular endothelial growth factor (VEGF), which stimulates mTOR.

The overproduction of skin cells and angiogenesis result in the initial appearance (largely flat red "spots" or diffuse redness) of facial AFs, which then progress to their characteristic fibrous popular appearance with the increasing proliferation of fibroblast-like cells and accumulation of collagen. Sirolimus binds with high specificity to mTOR, which inhibits its activity and ultimately downregulates cell proliferation. mTOR inhibition also modulates immunologic functions such as suppressing $\mathrm{T}$ lymphocyte and antibody production, and also neutrophil activity. Moreover, inhibiting the kinase also suppresses keratinocytic proliferation, and decreases VEGF production by inhibiting hypoxia-inducible factor expression and by directly downregulating VEGF-stimulated endothelial cell proliferation (31).

Treatments of facial AFs include vascular or ablative laser therapy, and physically destructive techniques such as shave excision and electrodessication. Despite these approaches, outcomes have been suboptimal (31). However, in a recent retrospective study (34) of 14 female patients treated with systemic oral Sirolimus (median 2 $\mathrm{mg}$ / day for a median treatment period of 12 months) for lymphangioleiomyomatosis (LAM) revealed a dramatic improvement in facial AFs. The overall findings indicated that Sirolimus is an effective long-term therapy for facial AFs with no evidence of resistance to long-term therapy.

A recent case study from a patient with TSC who was receiving oral Sirolimus after undergoing renal transplantation exhibited pronounced regression of her cutaneous AFs, which triggered its use as a topical agent in order to minimize systemic toxicity. Notably, investigators have recently developed a novel Rapamycin cream that is easy to compound, apply, does not cause local or systemic side effects, and that dramatically improves facial AFs (35). The following two clinical trials (non-blinded, uncontrolled single centered case series) evaluated topical mTOR inhibitor: Tarcolimus therapy with or without rapamycin, $0.2 \%$ topically, with 9 patients involved for a median treatment period of 3 months (36); and Sirolimus therapy, $0.4 \%$ topically 3 times a week, with 10 patients involved for a median treatment period of 10 month (37). No adverse effects were reported for either clinical trial although the small number of patients was considered the main limitation for both.

\section{A. Lung tumor}

Lymphangioleiomyomatosis (LAM) has been defined by the World Health Organization (WHO) classification of lung tumors as a tumor-like lesion (38). LAM can be included in the wide group of proliferative lesions named perivascular epithelioid cell tumors (39), described by the WHO as mesenchymal tumors composed of histologically and immunohistochemically distinctive perivascular epithelioid cells. LAM is a benign, rare and progressive cystic lung disease that almost exclusively affects females in their reproductive years, it occurs sporadically or in patients with TSC. About one-third of patients with TSC suffer from LAM (34); $13-38 \%$ of male patients with TSC develop LAM (39).

LAM consists of a frequently widespread and bilateral interstitial proliferation of smooth muscle cells arranged in a nodular and haphazard fashion around thin-walled, branching, lymphatic vascular channels. LAM is associated with dilated lymphatic vessels and cystic changes. Proliferating LAM cells include epitheloid cells that express estrogen and progesterone receptors, and also spindle-shaped cells that express proliferating cell nuclear antigen (PCNA), which is essential for replication and useful immunohistochemical marker of proliferation. Interestingly, LAM cells react with monoclonal antibody HMB45, which recognizes glycoprotein 100 (gp100), an antigen originally found in human melanoma cells. LAM cells also exhibit cell surface expression of CD44V6, a glycoprotein that binds hyaluronic acid and is associated with metastatic cancers. LAM cells also express Osteopontin; it is a regulator of CD44 splicing. Matrix metalloproteinases (MMPs) are found in LAM lung nodules and are likely mediators of parenchymal lung destruction (40).

\section{B. Treatment of lung tumor}

The treatment of LAM patients has in general 
been based on their symptoms/disease manifestations. For instance, chemical pleurodesis, the surgical obliteration of the pleural space, and lipid free diet (to decrease chyle flow), have been used to treat pleural effusions. Paracentesis and medium-chain triglyceride diet (MCT diet) have been used to treat ascites. Standard vaccinations are useful to prevent respiratory infections (41). A number of hormonal strategies have been used for treatment of LAM in the past, based on the expression of estrogen and progesterone receptors on epitheloid cells, such as bilateral oophorectomy and anti-estrogen therapy. Unfortunately, these methods yielded disparate results and no improvement in decreasing tumor size (41) Gonadotropin-releasing hormone (GnRH) analog therapy has been reported to have some benefit in patients with LAM. No clinical trials evaluating progesterone therapy have been conducted in LAM patients; however, retrospective studies have yielded controversial results for its use. In general, because of the inconclusive results and lack of clinical trials, hormonal therapy in patients with LAM is discouraged.

mTOR inhibitors are the treatment of choice for LAM patients. Sirolimus was the first drug approved by the US FDA for LAM treatment. Sirolimus (Rapamycin) and Everolimus (a Rapamycin analog) inhibit the proliferation/growth of LAM cells, and recent studies have shown that such inhibitors stabilize lung function in LAM patients. In a cohort study involving 38 patients with LAM treated with Sirolimus for 3.5 years, mTOR inhibitor therapy slowed down lung function decline as well as the increase in cystic lesions (42). Although a number of patients suffered from various adverse drug effects, therapy cessation was not needed. Another study also using Sirolimus (median dosage of $2 \mathrm{mg}$ / day for 12 months) that involved 89 patients (43 placebo and 46 Sirolimus) demonstrated improved pulmonary function in LAM patients during and after therapy (43). Adverse effects with mTOR inhibitor therapy included mouth ulceration, respiratory infection, diarrhea, hyperlipidemia and bone marrow suppression; the development of resistance is another primary concern during the course of treatment. A study of 15 patients showed that the use of Sirolimus in a smaller dose $(5 \mathrm{ng} / \mathrm{ml})$ led to the same frequency of side effects but with less effectiveness (44). Current therapy with mTOR inhibitors in LAM is indicated in patients with abnormal lung function, patients whose lung function is declining rapidly, and/or for the treatment of chylous effusions, and large AMLs and LAMs.

\section{A. Heart tumor}

Cardiac rhabdomyoma is the primary cardiac finding in people with TSC. There are rare cases of TSC patients that have coarctation of the aorta, renal artery stenosis, or thoracic or abdominal aneurysms (45). Cardiac rhabdomyoma is a non-malignant tumor that can occur anywhere in the heart, although it occurs most commonly in the ventricular septal myocardium. $70 \%$ to $90 \%$ of children with rhabdomyomas have TSC, and at least $50 \%$ of children with TSC have rhabdomyomas (45). The presence of multiple tumors would be consistent with a diagnosis of TSC.

Rhabdomyomas are benign and do not metastasize. They are usually well circumscribed, display an abnormal myocyte architecture with the pathognomonic "spider cells" present, and range in size from a few millimeters to several centimeters. The symptoms associated with these tumors are largely depends on their location, number and size. Most newborns and infants with rhabdomyomas are asymptomatic; however, asymptomatic patients can nonetheless have extensive cardiac involvement. Large tumors that substantially fill the ventricular cavity can obstruct blood outflow and lead to cyanosis; hemodynamic compromise can also result in congestive heart failure, might considered the main cause of death among TSC patients in the first decade of life. Heart failure occurs in $2 \%$ to $5 \%$ of infants and children with TSC- associated rhabdomyomas. Atrial tumors can compress the coronary arteries and lead to ischemia. Fortunately, most rhabdomyomas do not increase in size over time; they either get smaller or remain the same. Indeed, most tumors decrease in size over time and may be undetectable by echocardiography (45).

\section{B. Treatment of heart tumor}

Treatment of cardiac rhabdomyoma varies according to the particular case. For example, cases with CHF may be managed with digitalis, angiotensin converting enzyme inhibitiors and diuresis. If the heart failure is refractory, then surgery is indicated. In cases with hemodynamic compromise, especially in neonates, prostaglandin E may be initiated to stabilize the patient. When the cause of heart failure is inflow or outflow obstruction, "watchful waiting" may be indicated with the expectation that most cardiac rhabdomyomas will spontaneously regress over a period of months.

mTOR inhibitors may be effective in reducing the size of cardiac rhabdomyomas. However, because of the multiple side effects that accompany mTOR inhibitor treatment, therapy should only be considered in situations with hemodynamic 
compromise where there is the potential to avoid surgery. Indeed, given the low frequency of surgical resection for cardiac rhabdomyomas, mTOR inhibitors may be useful to induce tumor regression to alleviate symptoms. Based on limited observation, there do not appear to be significant cardiovascular side effects associated with mTOR inhibitors. However, while side effects are considered manageable in adults, some caution is in order given their inhibitory effects on the immune system, which may increase the risk of infections and the development of malignant tumors over the long term.

Sirolimus has been demonstrated to be a possible alternative to surgical treatment in patients needing tumor resection to alleviate hemodynamically significant critical outflow tract obstruction. In a recent case report of a baby boy born at 38 weeks of gestation with severe left ventricular outflow tract obstruction due to a large rhabdomyoma, Sirolimus was administrated orally $(0.5 \mathrm{mg} /$ day $)$ starting on day 10 of life and was continued for 24 days (46). Prophylactic co-trimoxazole (due to the immunosuppressive effect of mTOR inhibition) was administered although no episodes of infections were observed. On day 7 of treatment Sirolimus levels were $26 \mathrm{ng} / \mathrm{mL}$ so the dosage was reduced to $0.4 \mathrm{mg} /$ day. Serial echocardiography was performed to monitor the tumor size. On day 5 of treatment, the left ventricular outflow tract tumor started to decrease from $15 \times 12-\mathrm{mm}$ in size to $7 \mathrm{~mm} \times 8 \mathrm{~mm}$ with an overall dramatic reduction by day 24 to $5 \mathrm{~mm} \times 4 \mathrm{~mm}$. Sirolimus was discontinued, the patient was discharged from the hospital with no residual cardiac dysfunction (46). Although the patient's tumors increased slightly in size after discontinuation of Sirolimus, the gradient across the left ventricular outflow tract remained stable at the patient's most recent follow-up at 8 months of age. Thus, Sirolimus therapy has the potential to be particularly useful for rapid tumor regression of critically located rhabdomyomas in the neonatal heart, where the risk of surgical intervention is deemed too high. Close monitoring of patients and prophylactic antibiotic therapy may optimize outcomes in such cases.

A successful mTOR inhibitor therapy using Everolimus, a neonate presented with a massive cardiac rhabdomyom tumor. Everolimus treatment was favored rather than surgical resection and was found to effectively reduce tumor size, with hyponatremia being the only side effect noted. Given the possibility of relapse after therapy cessation, re-evaluation will be needed after a few months following cessation of mTOR inhibitor therapy to evaluate if there is a sustained tumoral response. Nevertheless, the early promising reports on the effectiveness for mTOR inhibitor therapy for the treatment of cardiac rhabdomyomas, allows physicians and patient families to have an option other than surgery, particularly for tumors requiring high risk surgical resection or where time the time to surgery is too long.

\section{A. Eye lesions}

One of the benign tumors hamartomas associated with TSC is retinal astrocytic hamartoma (RAH), a glial tumor of the retinal nerve fiber layer, which arises from retinal astrocytes. They are the most common ocular finding of TSC (present in $44 \%$ of patients) but may also be found rarely in patients with neurofibromatosis; RAH may be found in isolation in a normal person without systemic involvement, but they are usually found in association with TSC. They have a cream-white color depending on the extent of calcification, are well-circumscribed and elevated lesions that may be present at multiple or solitary sites. RAH commonly has a multilobulated, "mulberry" appearance, but can also appear flat and semitranslucent. Although RAHs in TSC generally remain stable, new RAHs can develop and some can progress. Indeed, the detrimental effects of RAHs may be underestimated, and there is currently no medical treatment available for controlling the size of these tumors (47).

\section{B. Treatment of eye lesions}

There is evidence that Sirolimus might be clinically useful for controlling the size of RAHs. For example, in one very recent study, treatment with Sirolimus for an average period of 7.9 months (initial dose of 1-2 $\mathrm{mg} /$ day and then titrated for a target trough concentration of $5-10 \mathrm{ng} / \mathrm{ml}$ ) dramatically decreased the size of RAHs, indicating that mTOR inhibition may provide effective treatment for these tumors in TSC. The limitations of this study included the small sample size and the short observation period. Moreover, whether these tumors increase in size after cessation of therapy was not evaluated. Thus, there is insufficient evidence to date to suggest the use of Sirolimus as a conventional method for treating RAHs; long-term studies need to be initiated (48).

In summary, we described all manifestations that associated with inherited TSC disease that involved in development multiple benign hamartomas of the brain, eyes, heart, lung, liver, skin and kidney as well as malignant kidney tumor as shown in Figure 1. In general, some individuals with TSC may demonstrate only dermatologic features of the disease while others may develop more serious neurologic or systemic manifestations including brain 
tumor. Several clinical trials listed in Table 1 using mTOR inhibitors showed positive response in reducing tumors in many organs of TSC patients. In certain cases, surgery may be needed in case of complications connected to tubers, SEGA and in risk of hemorrhage from kidney tumors.

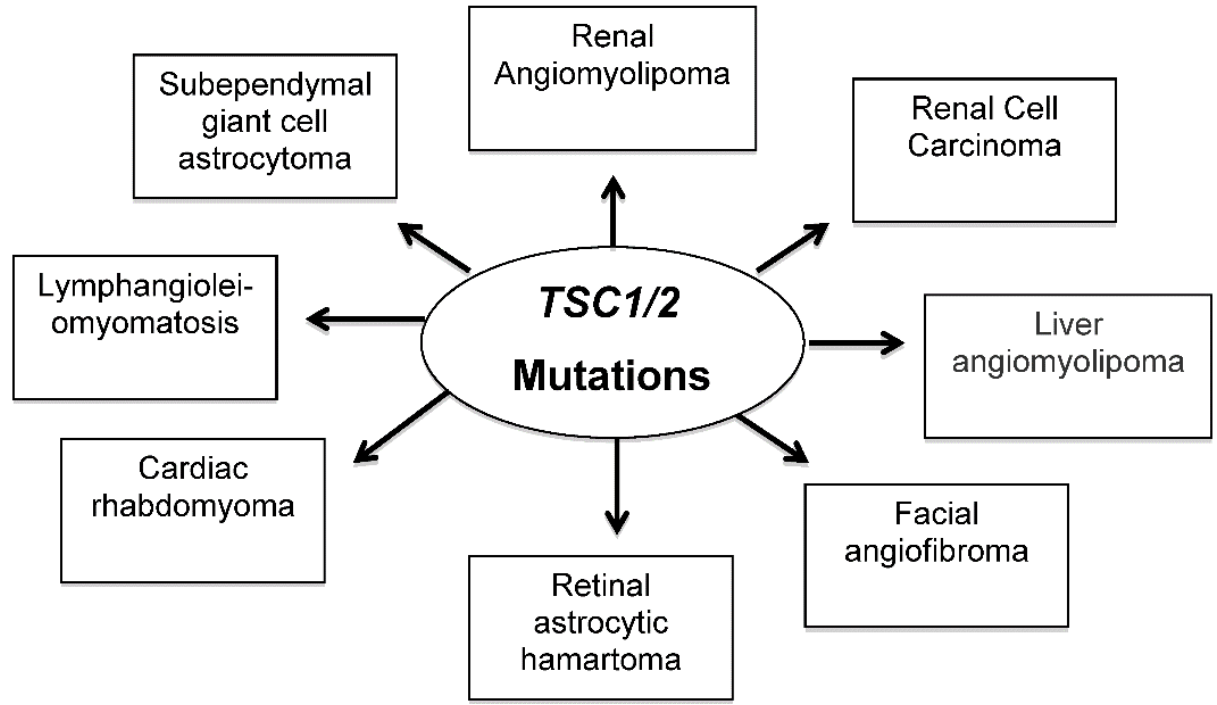

Figure 1. Mutations in TSCl/2 develop tumor in many organs including skin as well as disabling neurologic disorders.

Table 1: Summary of treatment TSC patients with mTOR inhibitors and its outcome on reducing tumor in many organs including skin tumor.

\begin{tabular}{|c|c|c|c|c|c|c|c|}
\hline Type of Study & $\begin{array}{l}\text { No. of } \\
\text { patients } \\
\text { enrolled in } \\
\text { the Study }\end{array}$ & Drug Dosage & $\begin{array}{l}\text { Median Drug } \\
\text { Treatment } \\
\text { (months) }\end{array}$ & Disease Type & Outcome & Main Side effects & Reference \\
\hline $\begin{array}{l}\text { Nonrandomized } \\
\text { open-label trial } \\
\text { (NCT00457808) }\end{array}$ & 25 & $\begin{array}{l}\text { Sirolimus } \\
\text { (Initial dose } \\
0.25 \mathrm{mg} / \mathrm{m}^{2} \text { ) }\end{array}$ & $\begin{array}{l}12 \text { Treatment } \\
24 \text { follow up }\end{array}$ & Renal AML & $\begin{array}{l}\text { Decrease the size of renal AML, } \\
\text { Improvement in pulmonary } \\
\text { Function. }\end{array}$ & $\begin{array}{l}\text { Diarrhea } \\
\text { Pyelonephritis } \\
\text { Stomatitis } \\
\text { Lung infection }\end{array}$ & $\begin{array}{l}\text { Bissler et al. } \\
2008(16)\end{array}$ \\
\hline $\begin{array}{l}\text { Multicentre } \\
\text { nonrandomized } \\
\text { open-label trial } 2 \\
\text { phase }\end{array}$ & 16 & $\begin{array}{l}\text { Sirolimus } \\
\text { (Initial dose } \\
0.5 \mathrm{mg} / \mathrm{m}^{2} \text { ) }\end{array}$ & 24 & Renal AML & $\begin{array}{l}\text { AML volume decrease during } \\
\text { therapy and increase after } \\
\text { therapy cessation. Also some } \\
\text { improvement in pulmonary } \\
\text { function has been achieved. }\end{array}$ & $\begin{array}{l}\text { Mouth ulcers } \\
\text { Respiratory infection } \\
\text { Proteinuria }\end{array}$ & $\begin{array}{l}\text { Davies et al. } \\
2011(17)\end{array}$ \\
\hline $\begin{array}{l}\text { Multicenter phase } 2 \\
\text { trial (NCT00126672) }\end{array}$ & 36 & $\begin{array}{l}\text { Everolimus } \\
\left(\text { Initial } 3 \mathrm{mg} / \mathrm{m}^{2}\right. \\
\left.\text { median } 5.3 \mathrm{mg} / \mathrm{m}^{2}\right)\end{array}$ & 24 & $\begin{array}{l}\text { Renal, Liver } \\
\text { AML and } \\
\text { SEGA }\end{array}$ & $\begin{array}{l}\text { Decrease in Tumor size, Serum } \\
\text { VEGF-D is useful in monitoring } \\
\text { Renal AML size. }\end{array}$ & $\begin{array}{l}\text { Stomatitis, } \\
\text { Hypertriglyceridemia } \\
\text { Hypercholesterolemia } \\
\text { Bone marrow } \\
\text { suppression }\end{array}$ & $\begin{array}{l}\text { Debora et al. } \\
2011(6)\end{array}$ \\
\hline $\begin{array}{l}\text { Non-blinded, } \\
\text { uncontrolled single } \\
\text { center case series }\end{array}$ & 9 & $\begin{array}{l}\text { Tacrolimus with or } \\
\text { without } \\
\text { rapamyicin } \\
(0.2 \%)\end{array}$ & 3 & $\begin{array}{l}\text { Facial } \\
\text { Angiofibroma }\end{array}$ & $\begin{array}{l}\text { Topical Treatment is a safe and } \\
\text { useful method in treatment of } \\
\text { Facial Angio-fibroma }\end{array}$ & Lack & $\begin{array}{l}\text { Wataya-Kane } \\
\text { da et al. } 2011 \\
(36)\end{array}$ \\
\hline $\begin{array}{l}\text { Randomized } \\
\text { Placebo Controlled } \\
\text { MILES Trial }\end{array}$ & $\begin{array}{l}89 \\
(43 \text { placebo } \\
\text { pts) }\end{array}$ & $\begin{array}{l}\text { Sirolmus } \\
\text { (2mg/day) }\end{array}$ & 12 & LAM & $\begin{array}{l}\text { Pulmonary Function } \\
\text { Improvement }\end{array}$ & $\begin{array}{l}\text { Mucositis } \\
\text { Diarrhea } \\
\text { Nausea } \\
\text { Hypercholesterolemia. }\end{array}$ & $\begin{array}{l}\text { McCormack } \\
2011(43)\end{array}$ \\
\hline $\begin{array}{l}\text { Non-blinded, } \\
\text { uncontrolled single } \\
\text { center case series }\end{array}$ & 10 & $\begin{array}{l}\text { Sirlolimus } \\
(0.4 \% 3 \text { times a } \\
\text { week) }\end{array}$ & 9 & $\begin{array}{l}\text { Facial } \\
\text { Angiofibroma }\end{array}$ & Treatment was safe and effective. & Lack & $\begin{array}{l}\text { Salido et al. } \\
2012(37)\end{array}$ \\
\hline $\begin{array}{l}\text { Multicenter, } \\
\text { double-blind, } \\
\text { placebo-controlled } \\
\text { phase } 3 \text { trial EXIST-2 } \\
\text { (NCT00790400) }\end{array}$ & $\begin{array}{l}118 \\
(39 \text { are } \\
\text { placebo } \\
\text { group) }\end{array}$ & $\begin{array}{l}\text { Everolimus } \\
(10 \mathrm{mg})\end{array}$ & 9.5 & Renal AML & $\begin{array}{l}\text { Decrease AML volume } \\
\text { (Everolimus have an acceptable } \\
\text { Safety profile to treat Renal } \\
\text { AML) }\end{array}$ & $\begin{array}{l}\text { Stomatitis } \\
\text { Nasopharyngitis } \\
\text { Acne-like skin lesions }\end{array}$ & $\begin{array}{l}\text { Bissler et al. } \\
2013(19)\end{array}$ \\
\hline $\begin{array}{l}\text { Prospective, } \\
\text { open-label 1-2 phase }\end{array}$ & 28 & $\begin{array}{l}\text { Everolimus } \\
\text { (Initial } 3 \mathrm{mg} / \mathrm{m}^{2}\end{array}$ & 34.2 & SEGA & $\begin{array}{l}\text { Marked reduction of tumor size, } \\
\text { no worsened hydrocephalus, }\end{array}$ & $\begin{array}{l}\text { Stomatitis } \\
\text { Respiratory infection }\end{array}$ & $\begin{array}{l}\text { Krueger et al. } \\
2010(8)\end{array}$ \\
\hline
\end{tabular}




\begin{tabular}{|c|c|c|c|c|c|c|c|}
\hline \multicolumn{2}{|l|}{ trial (NCT00411619) } & \multicolumn{3}{|l|}{ median $5.3 \mathrm{mg} / \mathrm{m}^{2}$ ) } & \multirow{2}{*}{$\begin{array}{l}\text { reduction of seizure frequency, } \\
\text { potential alternative for surgical } \\
\text { treatment, therapy is safe and } \\
\text { effective for long-term therapy. } \\
\text { Decrease volume of Renal AML } \\
\text { and Decrease volume of SEGA } \\
\text { tumor size. Drug safety for long } \\
\text { term use has been achieved }\end{array}$} & \multirow{2}{*}{$\begin{array}{l}\text { Sinustitis } \\
\text { Otitis media } \\
\text { Stomatitis } \\
\text { Mouth ulcers } \\
\text { Convulsion }\end{array}$} & \multirow{2}{*}{$\begin{array}{l}\text { Krueger et al. } \\
2013(9) \\
\text { Franz et al. } \\
2013(12) \\
\text { Franz et al. } \\
2014(11)\end{array}$} \\
\hline $\begin{array}{l}\text { Multicenter, } \\
\text { double-blind, } \\
\text { placebo-controlled } \\
\text { phase } 3 \text { trial EXIST-1 }\end{array}$ & $\begin{array}{l}117 / 39 \\
\text { placebo }\end{array}$ & $\begin{array}{l}\text { Everolimus (initial } \\
\text { dose } 4.5 \mathrm{mg} / \mathrm{m}^{2} \text { ) }\end{array}$ & 29.3 & SEGA & & & \\
\hline (NCT00789828) & $\begin{array}{l}44 / 14 \\
\text { placebo }\end{array}$ & & & Renal AML & & & \\
\hline & $\begin{array}{l}44 / 14 \\
\text { placebo }\end{array}$ & $\begin{array}{l}\text { Everolimus (initial } \\
\text { dose } 4.5 \mathrm{mg} / \mathrm{m}^{2} \text { ) }\end{array}$ & 9.5 & Renal AML & $\begin{array}{l}\text { Decrease volume of Renal AML } \\
\text { while treating SEGA with } \\
\text { everolimus. }\end{array}$ & & $\begin{array}{l}\text { Kingswood } \\
\text { et al. } 2014 \\
(15)\end{array}$ \\
\hline Cohort Study & 38 & $\begin{array}{l}\text { Sirolimus }(2.4 \\
+/-0.8 \mathrm{mg} / \text { day })\end{array}$ & 42 & LAM & Slow down lung function decline & $\begin{array}{l}\text { Hyper-lipidemia } \\
\text { Respiratory Infection } \\
\text { Stomatitis } \\
\text { Diarrhea }\end{array}$ & $\begin{array}{l}\text { Yao J, } 2014 \\
(42)\end{array}$ \\
\hline $\begin{array}{l}\text { Single-center } \\
\text { open-label series }\end{array}$ & 6 & $\begin{array}{l}\text { Sirolimus (3mg) } \\
\text { Everolimus (5mg) }\end{array}$ & 20 & SEGA & $\begin{array}{l}\text { Decrease in tumor size and } \\
\text { seizure frequency. }\end{array}$ & $\begin{array}{l}\text { Dyslipidemia } \\
\text { Gingivitis } \\
\text { Anorexia }\end{array}$ & $\begin{array}{l}\text { Cardamone } \\
\text { et al. } 2014 \\
(13)\end{array}$ \\
\hline Multicenter Study & 7 & $\begin{array}{l}\text { Sirolimus } 1.7+/- \\
0.49 \mathrm{mg} \text { per day }\end{array}$ & 7.9 & $\mathrm{RAH}$ & $\begin{array}{l}\text { Decrease or control the size of } \\
\text { RAH }\end{array}$ & $\begin{array}{l}\text { Oral Ulcers } \\
\text { Hyper-lipidemi } \\
\text { Irregular menses. }\end{array}$ & $\begin{array}{l}\text { Zhi-Qiao } \\
2015 \text { (48) }\end{array}$ \\
\hline $\begin{array}{l}\text { Single-center } \\
\text { open-label series }\end{array}$ & 15 & $\begin{array}{l}\text { Everolimus } \\
(2.5-7.5 \mathrm{mg})\end{array}$ & 13 & SEGA & $\begin{array}{l}\text { Tumor size reduction noted, } \\
\text { most rapid reduction occur in the } \\
\text { first } 3 \text { months of therapy }\end{array}$ & $\begin{array}{l}\text { Stomatitis } \\
\text { Respiratory infection } \\
\text { Hypertension } \\
\text { Secondary amenorrhea }\end{array}$ & $\begin{array}{l}\text { Trelinska et } \\
\text { al. } 2015(10)\end{array}$ \\
\hline $\begin{array}{l}\text { Retrospective case } \\
\text { series }\end{array}$ & 6 & $\begin{array}{l}\text { Sirolimus (For } 5 \\
\text { pts.) Everolimus } \\
\text { (for } 1 \text { pt.) for both } \\
\text { drug dosage was: } \\
4-5 \mathrm{mg} / \mathrm{m} 2 / \text { day }\end{array}$ & 60 & SEGA & $\begin{array}{l}\text { Tumor size Reduction more than } \\
50 \% \text {, Tumor regrowth with sub } \\
\text {-therapeutic drug dosage ( } 2.5 \\
\mathrm{mg} / \mathrm{m} 2 \text { /day) }\end{array}$ & $\begin{array}{l}\text { Decrease Growth rate } \\
\text { Irregular menses } \\
\text { Loss of appetite }\end{array}$ & $\begin{array}{l}\text { Weidman et } \\
\text { al. } 2015(7)\end{array}$ \\
\hline
\end{tabular}

\section{Acknowledgments}

This work was supported by grant from Merit Review Award from South Texas Veterans Healthcare System (to S.L.H.).

\section{Competing Interests}

The authors have declared that no competing interest exists.

\section{References}

1. Kotulska K, Borkowska J, Mandera M, Roszkowski M, Jurkiewicz E, Grajkowska W, Bilska M, Jóźwiak S. Congenital subependymal giant cell astrocytomas in patients with tuberous sclerosis complex. Childs Nervous Syst. 2014; 30:2037-42

2. O'Callaghan FJ, Martyn CN, Renowden S, Noakes M, Presdee D, Osborne JP. Subependymal nodules, giant cell astrocytomas and the tuberous sclerosis complex: a population-based study. Arch Dis Child, 2008; 93:751-4.

3. Scheithauer BW. The neuropathology of tuberous sclerosis. J Dermatol. 1992; $19: 897-903$

4. Sharma MC, Ralte AM, Gaekwad S, Santosh V, Shankar SK, Sarkar C. Subependymal giant cell astrocytoma-a clinicopathological study of 23 cases with special emphasis on histogenesis. Pathol Oncol Res. 2004; 10:219-24.

5. Campen CJ, Porter BE. Subependymal Giant Cell Astrocytoma (SEGA) Treatment Update. Curr Treat Options Neurol, 2011; 13:380-5.

6. Dabora SL, Franz DN, Ashwal S, Sagalowsky A, DiMario FJ Jr, Miles D, Cutler D, Krueger D, Uppot RN, Rabenou R, Camposano S, Paolini J, Fennessy F, Lee N, Woodrum C, Manola J, Garber J, Thiele EA. Multicentre case 2 trial of sirolimus for tuberous sclerosis: Sidney Angiomyolipomas and other tumors regress and VEGF-D levels decrease. PLoS One. 2011; 6: e23379

7. Weidman DR, Pole JD, Bouffet E, Taylor MD and Bartels U. Dose-level response rates of mTOR inhibition in tuberous sclerosis complex (TSC) related subependymal giant cell astrocytoma (SEGA). Pediatric Blood Cancer. 2015;: $1754-1760$
8. Krueger DA, Care MM, Holland K, Agricola K, Tudor C, Mangeshkar P, Wilson KA, Byars A, Sahmoud T, Franz DN. Everolimus for Subependymal giant-cell astrocytomas in tuberous sclerosis. N Engl J Med. 2010; 363:1801-11

9. Krueger DA, Care MM, Agricola K, Tudor C, Mays M, Franz DN. Everolimus long-term safety and efficacy in Subependymal Giant Cell Astrocytoma. Neurology. 2013; 80: 574-80.

10. Trelinska J, Dachowska I, Kotulska K, Baranska D, Fendler W, Jozwiak S, Mlynarski W. Factors affecting response to Everolimus therapy for Subependymal Giant cell Astrocytomas associated with tuberous sclerosis. Pediatr Blood Cancer, 2015, 62:616-21

11. Franz DN, Belousova E, Sparagana S, Bebin EM, Frost M, Kuperman R, Witt $\mathrm{O}$, Kohrman MH, Flamini JR, Wu JY, Curatolo P, de Vries PJ, Berkowitz N, Anak O, Niolat, Jozwiak K. Everolimus for Subependymal Giant Cell Astrocytoma in patients with Tuberous sclerosis complex: 2-year open-label extension of the randomised EXIST-1 study. Lancet Oncol, 2014:15:1513-20.

12. Franz DN, Belousova E, Sparagana S, Bebin EM, Frost M, Kuperman R, Witt O, Kohrman MH, Flamini JR, Wu JY, Curatolo P, de Vries PJ, Whittemore VH, Thiele EA, Ford JP, Shah G, Cauwel H, Lebwohl D, Sahmoud T, Jozwiak S. Efficacy and safety of everolimus for Subependymal Giant cell Astrocytomas associated with tuberous sclerosis complex (EXIST-1): a multicentre, randomised, placebo-controlled phase 3 trial. Lancet. 2013; 381:125-32.

13. Cardamone M, Flanagan D, Mowat D, Kennedy SE, Chopra M, Lawson JA. Mammalian target of rapamycin inhibitors for intractable epilepsy and subependymal giant cell astrocytomas in tuberous sclerosis complex. J Pediatric. 2014; 164: 1195-200.

14. Henske EP and Bissler JJ. Tuberous Sclerosis Complex: Fundamental Concepts in Diagnosis and Management Tuberous Sclerosis Alliance. 2013.

15. Kingswood JC, Jozwiak S, Belousova ED, Frost MD, Kuperman RA, Bebin EM, Korf BR, Flamini JR, Kohrman MH, Sparagana SP, Wu JY, Brechenmacher T, Stein K, Berkowitz N, Bissler JJ, Franz DN. The effect of Everolimus on renal Angiomyolipoma in patients with tuberous sclerosis complex being treated for Subependymal Giant cell Astrocytoma: subgroup results from the randomized, placebo-controlled, Phase 3 trial EXIST-1. Nephrol Dial Transplant, 2014; 29:1203-10.

16. Bissler JJ, McCormack FX, Young LR, Elwing JM, Chuck G, Leonard JM, Schmithorst VI, Laor T, Brody AS, Bean J, Salisbury S, Franz DN. Sirolimus for Angiomyolipoma in Tuberous Sclerosis complex or Lymphangioleiomyomatosis. N Engl J Med. 2008; 358:140-51.

17. Davies DM, de Vries PJ, Johnson SR, McCartney DL, Cox JA, Serra AL, Watson PC, Howe CI, Doyle T, Pointon K, Cross JJ, Tattersfield AE, Kingswood JC, Sampson JR. Sirolimus therapy for Angiomyolipoma in Tuberous Sclerosis and sporadic Lymphangioleiomyomatosis: a phase 2 trial. Clin Cancer Res. 2011; 17:4071-81. 
18. Kingswood JC, Jozwiak S, Belousova ED, Frost MD, Kuperman RA, Bebin EM, Korf BR, Flamini JR, Kohrman MH, Sparagana SP, Wu JY, Brechenmacher T, Stein K, Berkowitz N, Bissler JJ, Franz DN. The effect of Everolimus on renal Angiomyolipoma in patients with Tuberous Sclerosis complex being treated forSubependymal Giant cell Astrocytoma: subgroup results from the randomized, placebo-controlled, Phase 3 trialEXIST-1. Nephrol Dial Transplant. 2014; 29: 1203-10.

19. Bissler JJ, Kingswood JC, Radzikowska E, Zonnenberg BA, Frost M, Belousova E, Sauter M, Nonomura N, Brakemeier S, de-Vries PJ, Whittemore V, Chen D, Sahmoud T, Shah G, Lincy J, Lebwohl D, Budde K. Everolimus for angiomyolipoma associated with tuberous sclerosis complex or sporadic-lymphangioleiomyomatosis (EXIST-2): a multicenter, randomized, double-blind, placebo-controlled trial. Lancet, 2013; 381:817-24.

20. Freitas CSG, et al. Use of sirolimus in the treatment of Lymphangioleiomyomatosis: favorable responses in patients with different extrapulmonary manifestations. J Bras Pneumol.2015;41: 275-280.

21. Chang Y-H, Wang L-J and Chuang C-K. The efficacy and outcomes of urgent superselective trans-catheter arterial Embolization of patients with ruptured renal angiomyolipomas. J Trauma. 2007; 62: 1487-1490.

22. Washecka R. and Hanna M. Malignant renal tumors in tuberous sclerosis. Urology. 1991; 37:340-343.

23. Martin H. Voss, A. Ari Hakimi, Can G. Pham, A. Rose Brannon, Ying-Bei Chen, Luis F. Cunha, Oguz Akin, Han Liu, Shugaku Takeda, et al. Tumor Genetic Analyses of Patients with Metastatic Renal Cell Carcinoma and Extended Benefit from mTOR Inhibitor Therapy. Clin Cancer Res., 2014; 20: 1955-1964.

24. Kubo M, et al. Two different types of infantile renal cell carcinomas associated with tuberous sclerosis. Journal of Pediatric Surgery. 2011; 46: E37-E41

25. Pressey JG1, Wright JM, Geller JI, Joseph DB, Pressey CS and Kelly DR. Sirolimus therapy for Fibromatosis and multifocal Renal cell Carcinoma in a child with tuberous sclerosis complex. Pediatric Blood Cancer. 2010; 54:1035-7

26. Magdalena E. Sergiusz T, Izabela A, Malinowska T, Chekaluk Y, Pugh TJ, Wu C, Nussbaum RL, Seepo S, Dzik T, Kotulska K and Kwiatkowski DJ. A shower of second hit events as the cause of multifocal renal cell carcinoma in tuberous sclerosis complex. Hum. Mol. Genet. 2015; 24: 1836-1842.

27. Chang Z, Zhang JM, Ying JQ, Ge YP. Characteristics and treatment strategy of hepatic angiomyolipoma: a series of 94 patients collected from four institutions. J Gastrointestinal Liver Dis. 2011; 20:65-69.

28. Sasongko TH, Ismail NF, Malik NM, and Zabidi-Hussin HA. Rapamycin and its analogues (rapalogs) for Tuberous Sclerosis Complex-associated tumors: a systematic review on non-randomized studies using meta-analysis. Orphanet J Rare Dis. 2015; 10: 95.

29. Xiao-Wen Ge, Hai-Ying Zeng, Akesu Su-Jie, Min Du, Yuan Ji, Yun-Shan Tan, Ying-Yong Hou, and Jian-Fang $\mathrm{Xu}$. Hepatocellular carcinoma with concomitant hepatic angiomyolipoma and cavernous hemangioma in one patient. World J Gastroenterol. 2015; 21: 3414-3419.

30. Jung-Yi Lisa Chan, Kuo-Hsien Wang, Chia-Lang Fang and Wei-Yu Chen. Fibrous Papule of the Face, Similar to Tuberous Sclerosis Complex-Associated Angiofibroma, Shows Activation of the Mammalian Target of Rapamycin Pathway: Evidence for a Novel Therapeutic Strategy? PLoS One. 2014; 9: e89467.

31. Resham J. Vasani, K and Somaiya J. Facial Angiofibromas of Tuberous Sclerosis Treated with Topical Sirolimus in an Indian Patient Indian, J Dermatol, 2015; 60: 165-169.

32. Webb DW, Clarke A, Fryer A and Osborne JP. The cutaneous features of tuberous sclerosis: a population study. Br J Dermatol. 1996; 135:1-5.

33. Tyburczy ME, Wang JA, Li S, Thangapazham R, Chekaluk Y, Moss J, Kwiatkowski DJ and Darling TN. Sun exposure causes somatic second hit mutations and Angiofibroma development in Tuberous Sclerosis Complex. Hum Mol Genet. 2014; 23:2023-9.

34. Nathan N, Wang JA, Li S, Cowen EW, Haughey M, Moss J and Darling TN. Improvement of tuberous sclerosis complex (TSC) skin tumors during long-term treatment with oral Sirolimus. J Am Acad Dermatol. 2015; 73:802-8.

35. Wheless JW and Almoazen H. A novel topical rapamycin cream for the treatment of Facial Angiofibromas in tuberous sclerosis complex. J Child Neurol. 2013; 28:933-6.

36. Wataya-Kaneda M, Tanaka M, Nakamura A, Matsumoto S and Katayama A. A topical combination of Rapamycin and Tacrolimus for the treatment of Angiofibroma due to TSC: a pilot study of nine Japanese patients with TSC of different disease severity. Br J Dermatology. 2011; 165: 912-6.

37. Salido R, Garnacho-Saucedo G, Cuevas-Asencio I, Ruano J, Galán-Gutierrez M, Vélez A and MorenoGiménez JC. Sustained clinical effectiveness and favorable safety profile of tropical sirolimus for tuberous sclerosis-associated Facial angiofibroma. J Eur Acad Dermatology Venereol. 2012; 26:1315-8.

38. Sergio Harari, Olga Torre, Roberto Cassandro and Joel Moss. The changing face of a rare disease: lymphangiomyomatosis. European Respiratory Journal. 2015; 46:1471-85.

39. Meraj R, Wikenheiser-Brokamp KA, Young LR and McCormack FX. Lymphangioleiomyomatosis: new concepts in pathogenesis, diagnosis, and treatment. Semin Respir Crit Care Med. 2012; 33:486-97.

40. Travis WD, Colby TV, Corrin B, et al. Histological Typing of Lung and Pleural Tumours. Berlin Springer. 1999; 22-29.

41. Johnson, SR, Cordier JF, Lazor R, Cottin V, Costabel U, Harari S, et al, European Respiratory Society guidelines for the diagnosis and management of Lymphangioleiomyomatosis. Eur. Respir J. 2010; 35:14-26.
42. Jianhua Yao, Angelo M. Taveira-DaSilva, Amanda M. Jones, Patricia Julien-Williams, Mario Stylianou, Sustained effects of Sirolimus on lung function and cystic lung lesions in Lymphangioleiomyomatosis, Am J Respir Crit Care Med. 2014; 190: 1273-1282.

43. McCormack FX, Inoue $\mathrm{Y}$ and Moss J. Efficacy and safety of Sirolimus in Lymphangioleiomyomatosis. N Engl J Med. 2011; 364: 1595-1606.

44. Taveira-DaSilva AM and Moss J. Management of Lymphangioleiomyomatosis. F1000 Prime Rep. 2014; 6: 116.

45. Robert B. Hinton, Ashwin Prakash, Robb L. Romp, Darcy A. Krueger, and Timothy K. Knilans, cardiovascular manifestations of Tuberous sclerosis complex and a summary of a revised diagnostic criteria and surveillance and management recommendations from the international tuberous sclerosis consensus group. Journal of the American Heart Association. 2014; 3: e001493.

46. Breathnach C, Pears J, Franklin O, Webb D and McMahon CJ. Rapid regression of left ventricular outflow tract rhabdomyoma after sirolimus therapy. Pediatrics. 2011; 134: e1199-202.

47. Zhang ZQ, Shen C, Long Q, Yang ZK, Dai RP, Wang J, Zhang W, Pan Q, Zhu Z and $\mathrm{Xu}$ KF. Sirolimus for Retinal Astrocytic Hamartoma Associated with Tuberous Sclerosis Complex. Ophthalmology. 2015; 122:1947-

48. Zhi-Qiao Zhang, Cheng Shen, Qin Long, et al. Sirolimus for Retinal Astrocytic Hamartoma Associated with Tuberous Sclerosis Complex. Journal of the American Academy of Ophthalmology. 2015; 122:1947-1949. 